\title{
KOMPOSISI JENIS, KEPADATAN STOK, ASPEK BIOLOGI, DAN DISTRIBUSI KEPITING DI PERAIRAN ARAFURA
}

\author{
Wedjatmiko \\ Peneliti pada Balai Riset Perikanan Laut, Muara Baru-Jakarta \\ Teregristrasi I tanggal: 24 Juli 2007; Diterima setelah perbaikan tanggal: 3 April 2008; \\ Disetujui terbit tanggal: 10 Juni 2008
}

\begin{abstract}
ABSTRAK
Penelitian tentang komposisi jenis, kepadatan stok, aspek biologi dan distribusi kepiting di perairan Arafura telah dilakukan pada bulan Oktober-Nopember 2006. Kepiting adalah salah satu hewan yang termasuk golongan krustase dan merupakan bycatch dalam penangkapan udang. Survei trawl di Laut Arafura menunjukkan bahwa hasil tangkapan kepiting cukup tinggi, terbukti menduduki urutan ketiga pada tahun 2006, bahkan menduduki urutan kedua pada tahun 2003 setelah ikan demersal. Komposisi jenis kepiting diperoleh 6 famili, yaitu Portunidae (95,40\%), Calappidae (4,38\%), Majidae $(0,17 \%)$, Eriphiidae $(0,03 \%)$, Latreillidae $(0,01 \%)$, dan Parthenopidae $(0,01 \%)$. Sedangkan spesies dominan adalah Charybdis sp. (90,79\%) dari total famili Portunidae. Kepiting jenis tersebut adalah bycatch yang tidak komersial dan tidak dapat dikonsumsi (non edible crabs), karena ukurannya relatif kecil $(2-4 \mathrm{~cm})$ dan kandungan daging juga sangat sedikit. Penyebaran kepiting hampir terdapat di seluruh stasiun penelitian, dengan dominansi di sekitar perairan Digul dan perairan bagian barat Dolak, dengan laju tangkap antara 200-250 kg per jam.
\end{abstract}

\section{KATAKUNCl: $\quad$ komposisi, kepadatan stok, aspek biologi,distribusi, kepiting, Arafura}

\section{PENDAHULUAN}

Perairan Laut Arafura dan sebagian Maluku merupakan salah satu daerah penangkapan udang dan ikan demersal yang potensial. Usaha penangkapan udang di IBT sudah sejak lama dilakukan melalui patungan antara Indonesia dengan Jepang dan dalam pengembangan dewasa ini sudah banyak usaha PMDN, basis operasional kapal penangkapan ikan terutama terdapat di Sorong, Ambon, Tual, dan Benjina. Beberapa tahun terakhir ini, basis penangkapan ikan berkembang ke daerah Merauke, Kendari, dan Bitung. Jenis alat tangkap yang berkembang di perairan tersebut sebagian besar adalah alat tangkap perikanan demersal (jenis ikanikan dasar, udang, kepiting atau rajungan, dan lainlain).

Komoditas udang adalah merupakan tujuan utama dari alat tangkap tersebut karena udang mempunyai nilai ekonomis tinggi dan merupakan komoditas ekspor. Menurut Naamin (1987), rata-rata sekitar 30\% dari total nilai ekspor udang Indonesia setiap tahun berasal dari Laut Arafura dan 60\% antara lain merupakan udang jerbung (white shrimp) yang merupakan sasaran penangkapan. Sejak tahun 1984 tingkat pengusahaan udang sudah menunjukkan kecenderungan yang tinggi. Kini (2007) tingkat eksploitasi sumber daya udang di perairan Arafura tinggi sehingga hasil samping (bycatch) yang tidak termanfaatkan dan dibuang kembali ke laut (discard), termasuk kepiting juga ada kecenderungan terus meningkat.
Kepiting adalah salah satu hewan yang termasuk golongan krustase, dan merupakan bycatch dalam penangkapan udang. Jenis kepiting yang tertangkap di perairan Arafura tidak mempunyai nilai ekonomis penting dan pada umumnya tidak dapat dimakan (non edible crabs). Sedangkan jenis bycatch yang mempunyai nilai ekonomis, misalnya ikan kembung, tenggiri, bawal, kakap, dan kuro, pada umumnya dimanfaatkan oleh anak buah kapal untuk konsumsi di kapal, dibuat ikan asin atau kering sebagai oleholeh bagi keluarga atau dijual setelah sampai dengan di pelabuhan pangkalan. Salah satu perusahaan penangkapan udang yang berbasis di Sorong mengatakan bahwa setiap anak buah kapal diperbolehkan membawa bycatch dalam bentuk beku (untuk dibawa pulang) maksimal $30 \mathrm{~kg}$ untuk sekali trip (60 hari) dengan catatan apabila palkah tidak terisi penuh oleh udang. Sampai dengan sekarang di perairan Arafura belum ada yang memanfaatkan bycatch bagi keperluan bahan baku industri tepung ikan, maupun untuk kepentingan lainnya, sehingga banyak bycatch dibuang kembali ke laut (discard).

Bycatch yang tidak dimanfaatkan kemungkinan akan bertambah besar sejalan dengan bertambahnya jumlah armada trawl di Laut Arafura. Produksi ikan yang dihasilkan tidak hanya dipengaruhi oleh banyak sedikitnya jumlah armada trawl dan lokasi daerah penangkapan udang, tetapi juga oleh musim. Pada saat musim udang, jumlah bycatch yang dimanfaatkan cenderung sedikit. Hal ini ada kaitannya dengan kapasitas palka yang terbatas. 


\section{BAHAN DAN METODE}

Penelitian tentang komposisi jenis, kepadatan stok, aspek biologi, dan distribusi kepiting di perairan Arafura dilakukan pada bulan Oktober-Nopember 2006 di perairan Arafura menggunakan sarana KR. Bawal Putih I (180 GT) dengan posisi stasiun seperti tampak pada Gambar 1. Alat tangkap yang digunakan adalah jaring trawl tipe Thailand dengan konstruksi seperti pada Gambar 2. Panjang tali ris bawah (ground rope) sekitar $46 \mathrm{~m}$ dan tali ris atas (head rope) sekitar 47 $\mathrm{m}$.

Kegiatan penangkapan dilakukan pada siang hari jam 06.00-19.00 WIB setiap stasiun penangkapan dengan lama waktu penarikan jaring sekitar 1 jam,

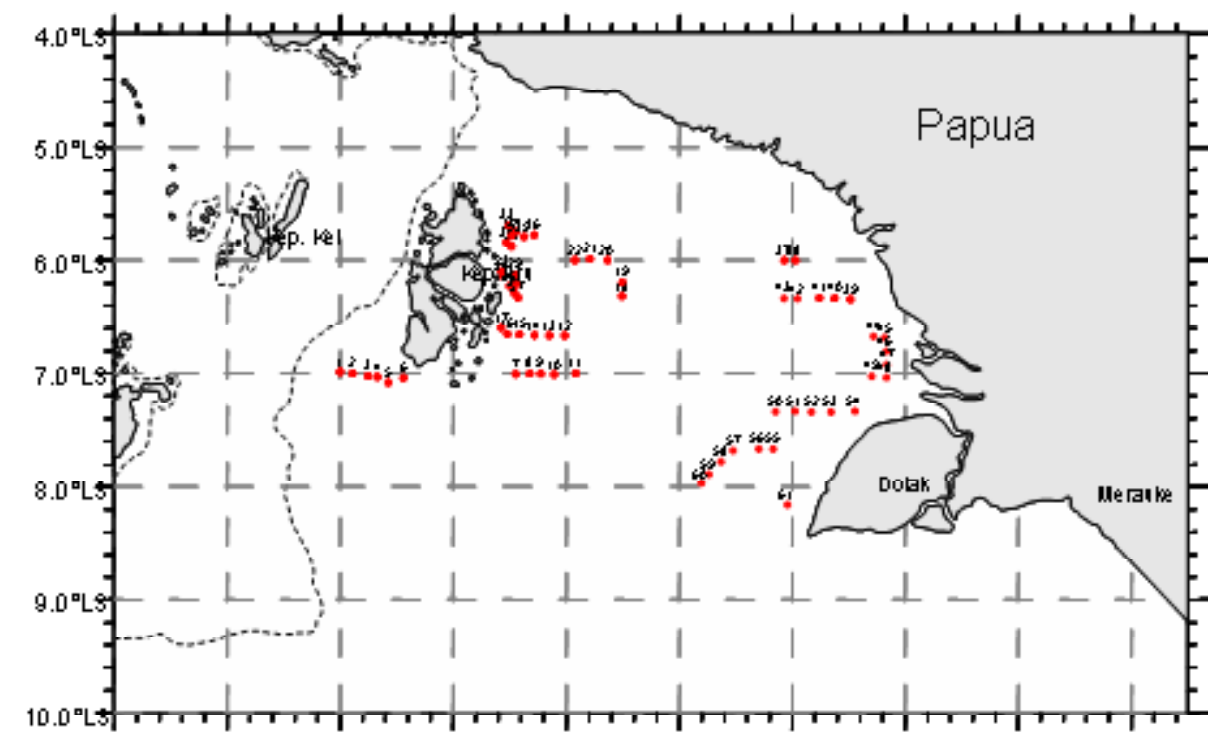

$131.5^{\circ} \mathrm{BT} 132.5^{\circ} \mathrm{BT} 133.5^{\circ} \mathrm{BT} 134.5^{\circ} \mathrm{BT} 135.5^{\circ} \mathrm{BT} 136.5^{\circ} \mathrm{BT} 137.5^{\circ} \mathrm{BT} 138.5^{\circ} \mathrm{BT} 139.5^{\circ} \mathrm{BT} 140.5^{\circ} \mathrm{BT}$

Gambar 1. Peta lokasi stasiun trawl di perairan Arafura, bulan Nopember 2006.
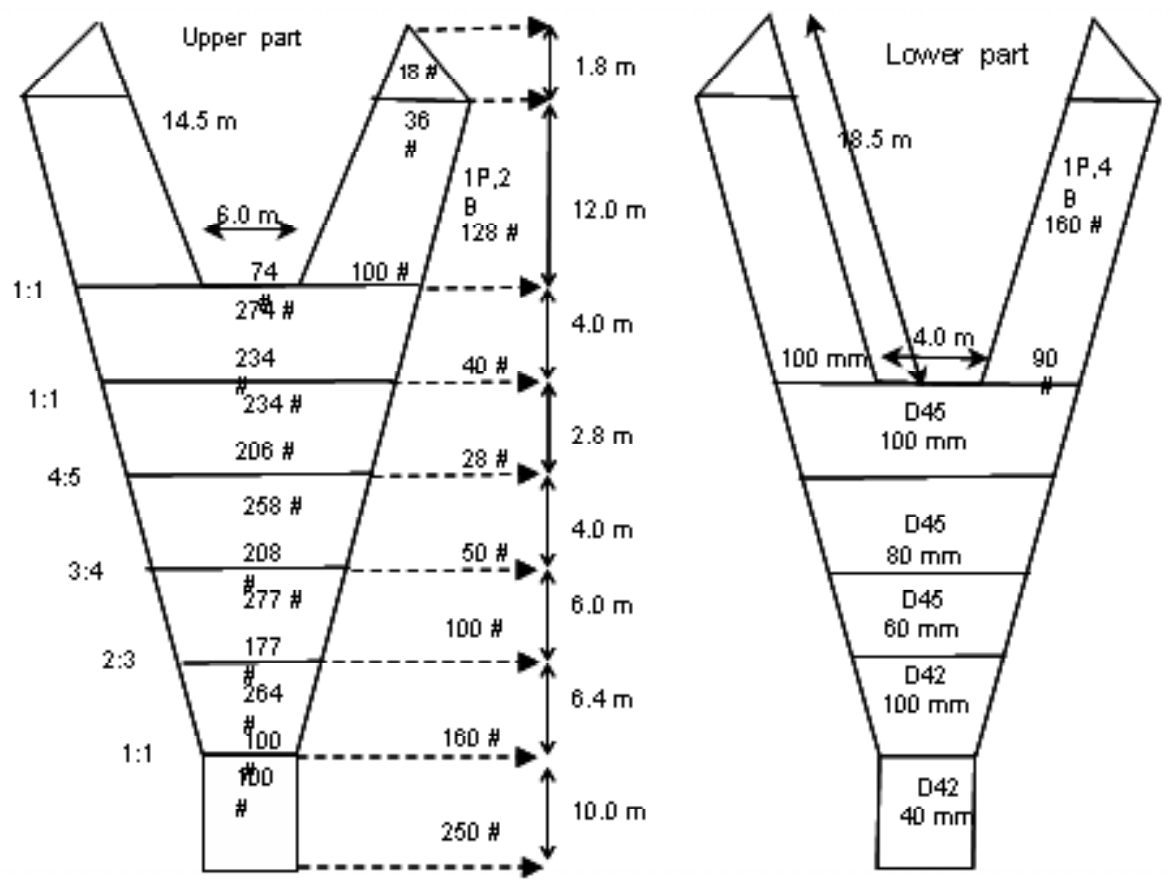

Gambar 2. Desain dan konstruksi jaring traw/yang digunakan dalam penelitian di perairan Arafura, bulan Nopember 2006. 
kecepatan kapal rata-rata 3 knot. Hasil tangkapan ditimbang dan disortir berdasarkan pada kelompok jenis ikan dan kepiting kemudian dicatat dalam sampling sheet. Identifikasi jenis kepiting, menggunakan referensi Allen (1977), Nakabo (2002), Mansoor et al. (1998), dan Carpenter \& Niem (1998a; 1998b; 1999; 2001a; 2001b; 2001c).

Untuk mendapatkan informasi pola sebaran, laju tangkap, dan kepadatan stok, data dianalisis menggunakan prinsip metode swept area menurut Shindu (1973), namun untuk memperoleh nilai bukaan mulut jaring yang akurat disesuaikan dengan keadaan di lapangan. Penentuan besar lebar bukaan mulut jaring tersebut dilakukan penghitungan dengan memperhitungkan bukaan otter board, kemudian penghitungan luas lahan yang disapu dilakukan pendekatan dengan persamaan yang sudah dimodifikasi oleh Tampubolon \& Monintja (1995), yakni:

$$
\mathrm{a}=\mathrm{SXDF}
$$

$\mathrm{S}=\mathrm{V} x \mathrm{t}$

di mana:

$$
\begin{array}{ll}
\mathrm{a} & =\text { luas daerah yang disapu }\left(\mathrm{mil}^{2}\right) \\
\mathrm{S} & =\text { jarak sapuan (mil) } \\
\mathrm{DF} & =\text { lebar bukaan mulut jaring } \\
\mathrm{V} & =\text { kecepatan kapal } \\
\mathrm{t} & =\text { waktu towing }
\end{array}
$$

Untuk menghitung biomassa atau kepadatan per luas lahan digunakan metode sapuan menurut Sparre \& Venema (1992) dengan persamaan:

$$
\mathrm{B}=(\mathrm{cw} / \mathrm{t}) /(\mathrm{a} / \mathrm{t}) \mathrm{kg} / \mathrm{mil}^{2}
$$

di mana:

$\mathrm{B}=$ biomassa ikan (kepiting)

$\mathrm{cw} / \mathrm{t}=$ hasil ikan (kepiting) setiap tarikan per jam

$\mathrm{a} / \mathrm{t}=$ luas sapuan tiap jam

Untuk mendapatkan total biomassa ikan pada daerah penelitian (kepadatan stok) digunakan rumus:

$$
\mathrm{B}=(\mathrm{A} \times \mathrm{Ca}) / \mathrm{f}
$$

di mana:

$\mathrm{B}=$ total biomassa (ton)

$A=$ total luas daerah survei $\left(\mathrm{mil}^{2}\right)$

$\mathrm{f}$ = escapment factor adalah perbandingan jumlah ikan (kepiting) yang tertangkap dan yang lolos, pada umumnya di Asia Tenggara menggunakan nilai 0,5 (Isarankura, 1971; Saeger et al., 1980)

\section{HASIL DAN BAHASAN}

\section{Komposisi Hasil Tangkapan}

Komposisi hasil tangkapan traw/ hasil penelitian tahun 2006 didominansi oleh ikan demersal dengan laju tangkap 177,82 kg/jam (58,89\%), diikuti oleh ikan pelagis dengan laju tangkap $34,31 \mathrm{~kg} / \mathrm{jam}(11,36 \%)$. Sedangkan kepiting menduduki urutan ketiga dengan laju tangkap 29,85 kg/jam (9,88\%). Sementara udang

\begin{tabular}{|c|c|c|c|c|}
\hline No. & Kelompok jenis & Hasil tangkapan $(\mathbf{k g})$ & Laju tangkap (kg/jam) & Persentase (\%) \\
\hline 1. & Ikan demersal & $10.669,44$ & 177,82 & 58,89 \\
\hline 2. & Ikan pelagis & $2.058,69$ & 34,31 & 11,36 \\
\hline 3. & Kepiting & $1.790,82$ & 29,85 & 9,88 \\
\hline 4. & Udang & $1.413,36$ & 23,56 & 7,80 \\
\hline 5. & Cumi-cumi & 828,35 & 13,81 & 4,57 \\
\hline 6. & Ikan pari & 612,35 & 10,21 & 3,38 \\
\hline 7. & Ubur-ubur & 219,60 & 3,66 & 1,21 \\
\hline 8. & Bulu babi & 177,89 & 2,96 & 0,98 \\
\hline 9. & Ketimun laut & 176,63 & 2,94 & 0,97 \\
\hline 10. & Ikan cucut & 116,43 & 1,94 & 0,64 \\
\hline 11. & Kerang & 49,34 & 0,82 & 0,27 \\
\hline 12. & Bintang laut & 6,00 & 0,10 & 0,03 \\
\hline & Total & $18.118,90$ & 301,98 & 100,00 \\
\hline
\end{tabular}
yang merupakan tujuan utama penangkapan menggunakan traw/berada diurutan keempat, dengan laju tangkap 23,56 kg/jam (7,80\%). Hasil tangkapan cumi-cumi, ikan pari, ikan cucut, dan komoditas non ikan lainnya kurang dari $5 \%$ (Tabel 1).

Tabel 1. Komposisi hasil tangkapan traw/berdasarkan pada kelompok jenis di perairan Arafura tahun 2006 
Laju tangkap kepiting sangat dominan pada penelitian tahun 2003 di tempat yang sama (di Laut Arafura). Hasil tangkapan kepiting mencapai $32 \%$ atau menduduki urutan kedua setelah hasil tangkapan ikan demersal (55,69\%), sedangkan udang yang merupakan tujuan utama hanya 3,86\% (Tabel 2). Hal ini mungkin disebabkan oleh spesifikasi trawl yang digunakan tidak sesuai untuk menangkap udang. Seperti diketahui bahwa desain trawl untuk tujuan menangkap ikan demersal dan udang adalah berbeda. Salah satu perbedaan yang mendasar bahwa untuk menangkap udang, tali ris bawah (ground rope) dilengkapi dengan rantai pengejut (ticker chain).

Perkembangan produksi kepiting di perairan Arafura berdasarkan pada hasil penelitian tahun sebelumnya (Wedjatmiko et al., 2003), menunjukan terjadi peningkatan dari tahun 2001-2003. Namun, pada tahun 2006 produksi kepiting terlihat menurun kembali, dari $32,08 \%$ pada tahun 2003 menjadi $9,88 \%$ pada tahun 2006 (Gambar 3). Penurunan produksi kepiting erat kaitan dengan ada informasi bahwa, akhir-akhir ini banyak bycatch berupa ikan ekonomis yang dimanfaatkan, di jual sebagai tambahan penghasilan anak buah kapal. Dengan demikian, bycatch yang dibuang kembali ke laut (discard) semakin sedikit, sementara kepiting adalah binatang pemakan bangkai (scavenger).

Khusus untuk kepiting yang tertangkap di perairan Arafura, dari hasil identifikasi diperoleh 6 famili yaitu Portunidae (95,402\%), Calappidae (4,384\%), Majidae $(0,173 \%)$, Eriphiidae $(0,029 \%)$, Latreillidae $(0,011 \%)$, dan Parthenopidae $(0,001 \%)$. Dengan demikian, komposisi kepiting yang tertangkap di perairan Arafura didominasi oleh famili Portunidae. Kepiting tersebut sebagian besar merupakan jenis non komersial yang tidak dikonsumsi oleh manusia, khususnya dari jenis Charybdis sp. Jenis kepiting yang dikonsumsi manusia jenisnya hanya sedikit yaitu Portunus pelagicus, Charybdis feriviatus, dan Portunus sanguinolentus yang jumlahnya sangat minim, yaitu kurang dari $1 \%$ (Tabel 3).Beberapa jenis kepiting yang banyak tertangkap di Laut Arafura tersebut diperlihatkan pada Gambar (4a-f).

Tabel 2. Komposisi hasil tangkapan traw/berdasarkan pada kelompok jenis di perairan Arafura, tahun 2003

\begin{tabular}{clcc}
\hline No. & Kelompok & Hasil Tangkapan $\mathbf{( k g )}$ & $(\%)$ \\
\hline 1. & Ikan demersal & $10.830,73$ & 55,69 \\
2. & Kepiting & $6.239,69$ & 32,08 \\
3. & Udang & 750,44 & 3,86 \\
4. & Timun laut & 488,76 & 2,51 \\
5. & Kerang & 395,20 & 2,03 \\
6. & Cumi-cumi & 312,00 & 1,60 \\
7. & Ikan pelagis & 270,49 & 1,39 \\
8. & Ikan pari & 132,37 & 0,68 \\
9. & Ikan cucut & 28,44 & 0,15 \\
\hline & Jumlah & $\mathbf{1 9 . 4 4 8 , 1 2}$ & $\mathbf{1 0 0 , 0 0}$
\end{tabular}

Sumber: Wedjatmiko et al. (2003)

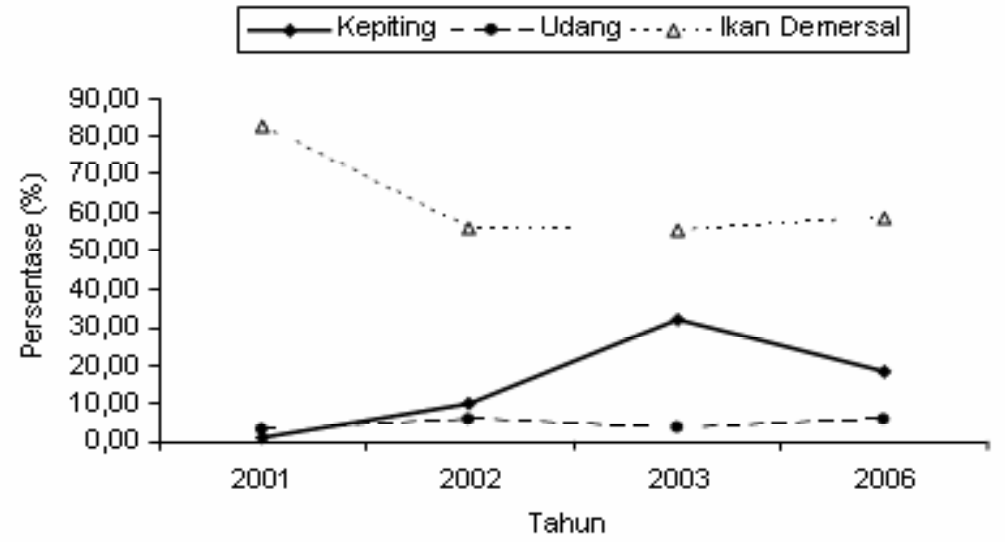

Gambar 3. Perkembangan produksi kepiting, udang, dan ikan demersal di perairan Arafura (tahun 2001 -2006). 
Komposisi Jenis, Kepadatan Stok .... dan Distribusi Kepiting di Perairan Arafura (Wedjatmiko)

Tabel 3. Komposisi hasil tangkapan kepiting di perairan Arafura, tahun 2006

\begin{tabular}{|c|c|c|c|c|}
\hline Family & Species & Bobot $(\mathbf{k g})$ & Jumlah (ekor) & $\%$ \\
\hline \multirow[t]{6}{*}{ Portunidae } & Charybdis sp. & $1.624,96$ & 167.653 & 90,79 \\
\hline & Charybdis feriviatus & 68,60 & 540 & 3,83 \\
\hline & Portunus pelagicus & 12,95 & 120 & 0,72 \\
\hline & Portunus sp. & 0,70 & 3 & 0,04 \\
\hline & Portunus sanguinolentus & 0,30 & 2 & 0,02 \\
\hline & Jumlah & $1.707,51$ & 168.317 & 95,40 \\
\hline \multirow[t]{3}{*}{ Calappidae } & Matuta victor & 71,69 & 7.359 & 4,00 \\
\hline & Calappa philargius & 6,77 & 119 & 0,38 \\
\hline & Jumlah & 78,46 & 7.477 & 4,38 \\
\hline Majidae & Majidae & 3,10 & 105 & 0,17 \\
\hline Eriphiidae & Eriphiidae & 0,52 & 14 & 0,03 \\
\hline Latreillidae & Latreillidae & 0,20 & 20 & 0,01 \\
\hline \multirow[t]{2}{*}{ Parthenopidae } & Parthenopidae sp. & 0,02 & 1 & 0,01 \\
\hline & Total & $1.789,82$ & 175.934 & 100,00 \\
\hline
\end{tabular}

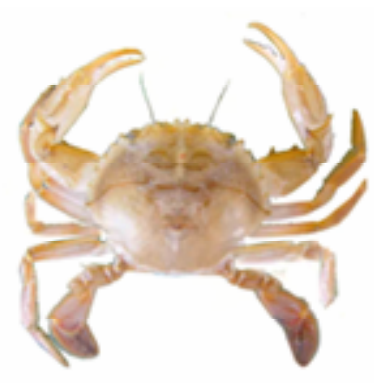

Gambar 4a. Charybdis sp.

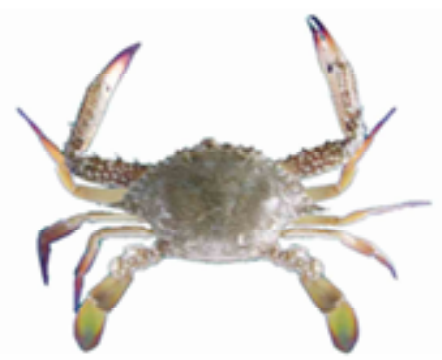

Gambar 4c. Portunus pelagicus.

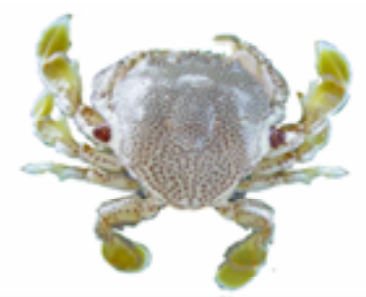

Gambar 4e. Matuta victor.

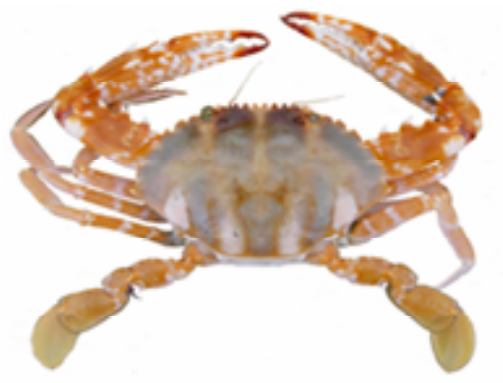

Gambar 4b. Charybdis feriviatus.

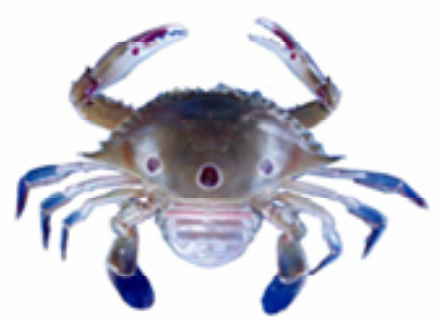

Gambar 4d. Portunus sanguinolentus.

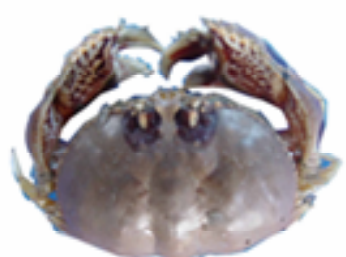

Gambar 4f. Calappa philargius. 


\section{Kepadatan Stok Kepiting}

Selama kegiatan berlangsung, telah dilakukan 61 kali operasi penangkapan atau 61 stasiun dengan menggunakan stern traw/pada cruise track yang telah ditentukan sebelumnya. Total hasil tangkap kepiting adalah $1.789,82 \mathrm{~kg}$ (175.934 ekor) atau rata-rata pertarikan $29,4 \mathrm{~kg}$ (2.884 ekor). Bobot rata-rata kepiting yang tertangkap sekitar $35 \mathrm{~g}$.

Total luas lahan yang disapu jaring traw/ selama 61 kali operasi dengan bukaan mulut jaring rata-rata 13,51 m dan kecepatan kapal saat operasi adalah 3 knot per jam, adalah $2.479,83 \mathrm{mil}^{2}$, sedangkan luas lahan di perairan Arafura yang disurvei seluas 28.800 $\mathrm{mil}^{2}$ dengan hasil tangkap rata-rata kepiting/jam tarikan 29,4 kg (sekitar 2.884 ekor), sehingga diperoleh besar biomasssa sekitar $341.557,08 \mathrm{~kg}$ (sekitar 10.246.712 ekor).

\section{Biologi}

Ukuran panjang karapas kepiting (Charybdis sp.) yang merupakan jenis kepiting yang paling dominan $(90,789 \%)$ adalah berkisar $20-39 \mathrm{~mm}$, dengan dominansi pada ukuran 30-34 mm (Gambar 5). Mengingat ukuran kepiting yang relatif kecil tersebut, sampai tidak memungkinkan untuk dikonsumsi oleh manusia karena kandungan daging yang sangat minim, namun tidak menutup kemungkinan karapas kepiting tersebut yang merupakan bagian terbesar dari tubuh kepiting mengandung kalsium atau chitin, untuk bahan baku produk tertentu.

\section{Distribusi}

Distribusi atau penyebaran kepiting di perairan Arafura menunjukkan bahwa hampir seluruh stasiun penelitian dijumpai kepiting, namun sebaran tertinggi

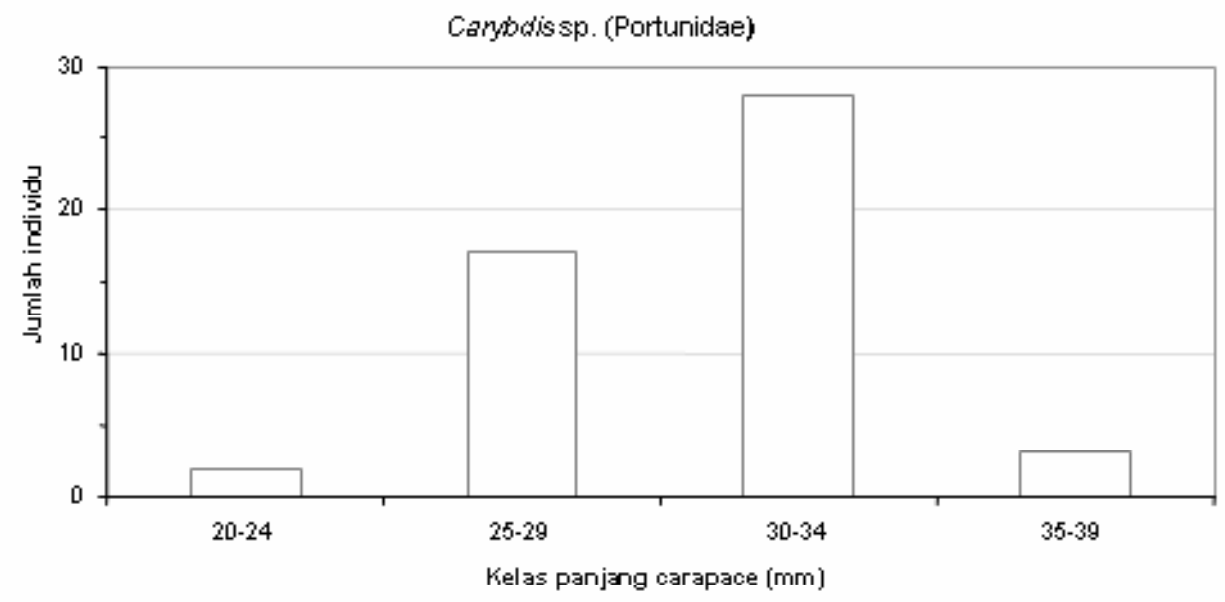

Gambar 5. Histogram kelas panjang karapas kepiting Charybdis sp., tahun 2006.

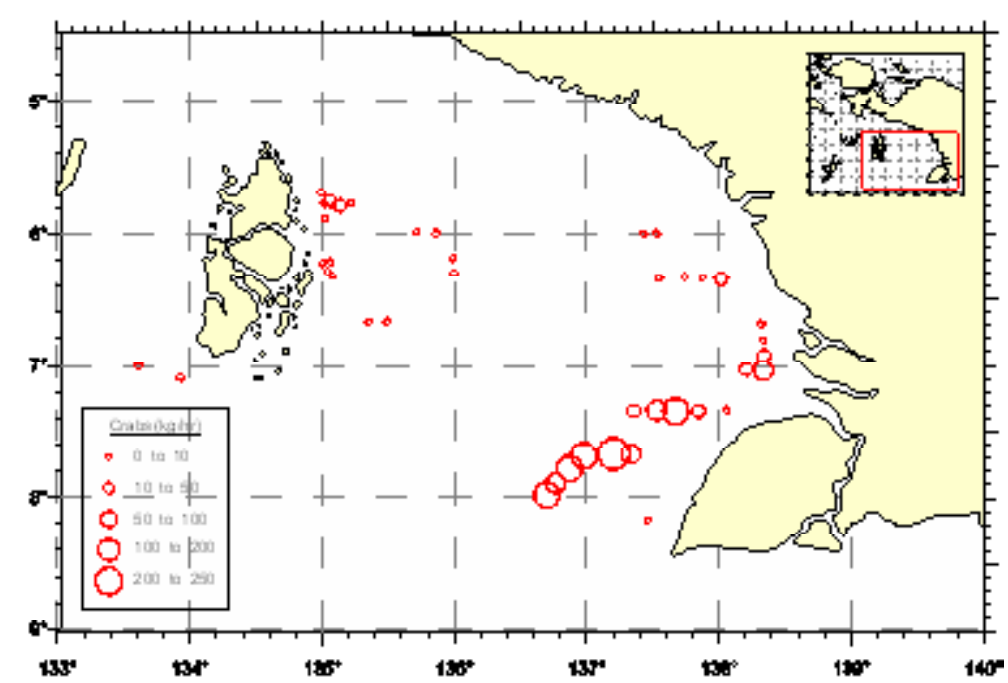

Gambar 6. Peta distribusi kepiting (crabs) di perairan Arafura, tahun 2006. 
terdapat di perairan sebelah barat Dolak dan perairan Digul, dengan laju tangkap 200-250 kg/jam (Gambar $6)$.

\section{KESIMPULAN}

Berdasarkan pada hasil penelitian terhadap komposisi jenis, kepadatan stok, aspek biologi, dan distribusi kepiting di perairan Arafura dapat disimpulkan beberapa hal sebagai berikut:

1. Hasil tangkapan traw/menunjukkan bahwa jenis kepiting di perairan Arafura memberikan kontribusi cukup tinggi, yaitu menduduki urutan ketiga setelah ikan demersal.

2. Komposisi jenis kepiting diperoleh 6 famili, yaitu Portunidae (95,40\%), Calappidae (4,38\%), Majidae $(0,17 \%)$, Eriphiidae $(0,03 \%)$, Latreillidae $(0,01 \%)$, dan Parthenopidae (0,01\%). Sedangkan spesies dominan adalah Charybdis sp. (90,79\%) dari famili Portunidae.

3. Kepiting jenis Charybdis sp. merupakan bycatch yang tidak komersial dan tidak dikonsumsi manusia (non edible crabs) karena ukurannya yang relatif kecil dan kandungan dagingnya juga sangat sedikit.

4. Penyebaran kepiting hampir terdapat di seluruh stasiun penelitian, dengan rata-rata laju tangkap 29,85 kg/jam. Di sekitar perairan Digul dan perairan bagian barat Dolak, diperoleh laju tangkap 200$250 \mathrm{~kg}$ per jam.

\section{PERSANTUNAN}

Kegiatan dari hasil riset sumber daya perikanan demersal di perairan Arafura, T.A. 2006, di Balai Riset Perikanan Laut-Muara Baru, Jakarta.

\section{DAFTAR PUSTAKA}

Allen, G. 1997. Marine Fishes of South-East Asia. Western Australia Museum. 292 pp.

Carpenter, K. E. \& V. H. Niem. 1998a. The living marine reources of the Western Central Pacific. Vol.1. Seaweeds, Corals, Bivalvas, and Gastropods. Species Identification Guide for Fishery Purposes. Food and Agriculture Organization of the United Nations. Rome 1998.

Carpenter, K. E. \& V. H. Niem. 1998b. The living marine reources of the Western Central Pacific. Vol.2.
Cephalopods, Crustaceans, Holothurians, and Sharks. FAO Species Identification Guide for Fishery Purposes. Food and Agriculture Organization of the United Nations. Rome 1998.

Carpenter, K. E. \& V. H. Niem. 1999. The living marine reources of the Western Central Pacific. Vol.3. Batoid Fishes, Chimaeras, and Bony Fishes. Part 1 (Elopidae to Linophrynidae). FAO Species Identification Guide for Fishery Purposes. Food and Agriculture Organization of the United Nations. Rome 1999.

Carpenter, K. E. \& V. H. Niem. 2001a. The living marine reources of the Western Central Pacific. Vol.4. Bony Fishes. Part 2 (Mugillidae to Carangidae). FAO Species Identification Guide for Fishery Purposes. Food and Agriculture Organization of the United Nations. Rome 1999.

Carpenter, K. E. \& V. H. Niem. 2001b. The living marine reources of the Western Central Pacific. Vol.5. Bony Fishes. Part 3 (Menidae to Pornacentridae). FAO Species Identification Guide for Fishery Purposes. Food and Agriculture Organization of the United Nations. Rome 2001.

Carpenter, K. E. \& V. H. Niem. 2001c. The living marine reources of the Western Central Pacific. Vol.6. Bony Fishes. Part 4 (Labridae to Latimeriidae) Estuarine Crocodiles, Sea Turtles, Sea Snakes, and Marine Mammals. FAO Species Identification Guide for Fishery Purposes. Food and Agriculture Organization of the United Nations. Rome 2001.

Isarankura, A. P. 1971. Assessment of Stocks of Demersal Fish off the West Coast of Thailand and Malaysia. FAO/UNDP. Indian Ocean Programme. Rome. IOC/DEV/71/20. x+20 pp.

Mansoor, M. I., H. Kohno, I H. Ida, H. T. Nakamura, Z. Aznan \& S. Abdullah. 1998. Field Guide Important Commersial Marine Fishes of the South China Sea. SEAFDEC MFRDMD/SP/2.

Monintja D. R \& G. H. Tampubolon. 1989. Pendugaan stok ikan demersal dengan metode swept area. Proyek Pengembangan IImu Kelautan. Institut Pertanian Bogor. Bogor. 10 pp.

Naamin. N. 1987. Dinamika populasi udang jerbung (Penaeus merguiensis de Man) di perairan Arafura dan alternatif pengelolaannya. Jurnal Penelitian Perikanan Laut. No.42. Balai Penelitian Perikanan Laut. Jakarta. 15-24. 
Nakabo, T. 2002. Fishes of Japan, with Pectoral Keys to the Species. English edition I and II. Tokay Univercity Press. Tokio. 1.747 pp.

Saeger, J., P. Martosubroto, \& D. Pauly. 1980. First report of the Indonesia German demersal fisheries project (Result of trawl survey in the Sunda Shelf Area). Marine Fisheries Report. (1). 46 pp.

Shindo, S. 1973. General review of the trawl fishery and the demersal fish stock of the South China Sea. FAO Fish. Tech Pap. (120). 49 pp.

Sparre, P. \& S. C. Venema. 1992. Introduction to tropical fish stock assessment. Part 1 Manual. Rome FAO. Fish. Tech..Pap. (306/1). 23 pp.
Tampubolon, G. H. \& D. R. Monintja. 1995. Pendugaan stok ikan demersal dengan metode swept area. Cruise Sandipati Bahari. Proyek Pengembangan dan Pemanfaatan Sumber Daya Perikanan Laut. Direktorat Jenderal Perikanan. iii+12 pp.

Wedjatmiko, Suprapto, \& B. Sadhotomo. 2003. Laporan Hasil Penelitian Sumber Daya Ikan Demersal di Perairan Arafura. Balai Riset Perikanan Laut. Jakarta. 60 pp. 